\title{
Treatment of chronic hepatitis B with interferon: Long term follow-up
}

\author{
JeAN-PIERRE ViLlENEUVE MD, BERNARD WiLlEMS MD
}

\begin{abstract}
J-P Villeneuve, B Willems. Treatment of chronic hepatitis B with interferon: A long term follow-up. Can J Gastroenterol 1996;10(1):21-25. The aim of treatment of chronic hepatitis B with interferon is to induce a transition from the replicative phase of the disease to a nonreplicative state, with loss of hepatitis B virus (HBV)-DNA, seroconversion from hepatitis $\mathrm{B}$ e antigen (HBeAg)-positive to anti-HBe antibody-positive, and normalization of liver enzymes. The authors' experience in 22 patients with chronic hepatitis B treated with recombinant human interferon alpha- $2 \mathrm{~b}$ (5 $\mathrm{MU} / \mathrm{m}^{2}$ subcutaneously three times/week for 16 weeks) is reported. Before treatment all patients had been positive for hepatitis B surface antigen (HBsAg) and $\mathrm{HBeAg}$ for at least six months, had abnormal serum aminotransferases, had no evidence of hepatitis D or human immunodeficiency virus (HIV) infection and had compensated liver disease. Eleven of 22 patients (50\%) responded to treatment with loss of $\mathrm{HBeAg}$ and appearance of anti-HBe antibodies, and normalization of serum aminotransferases within six months of interferon cessation. Patients were followed for $3.4 \pm 1.2$ years after treatment. Ten of 11 responders remained negative for $\mathrm{HBe} \mathrm{Ag}$ and $\mathrm{HBV}$-DNA; one patient relapsed and responded to a second course of interferon with loss of $\mathrm{HBeAg}$ and HBV-DNA. Seven of the 11 nonresponders underwent spontaneous $(n=5)$ or retreatment-induced $(n=2)$ seroconversion from $\mathrm{HBeAg}$ to anti-HBe and loss of HBV-DNA during follow-up. The other four nonresponders remained positive for $\mathrm{HBeAg}$ and HBV-DNA; three of the four progressed to decompensated liver disease. It is concluded that interferon is an effective treatment of chronic hepatitis B in $50 \%$ of patients with features similar to those used as selection criteria in the present study. These criteria probably also identify patients who have a high likelihood of spontaneous $\mathrm{HBeAg}$ to anti-HBe seroconversion, and it is possible that the benefit of interferon is its acceleration of this seroconversion.
\end{abstract}

Key Words: Chronic hepatitis B, Interferon, Treatment

\section{Traitement de l'hépatite chronique $\mathrm{B}$ par l'interféron: suivi a long terme}

RÉSUMÉ : L'objectif du traitement de l'hépatite chronique B par l'interféron et d'induire une transition de la phase réplicative de la maladie à la phase non-réplicative. Cette transition se manifeste par une disparition de l'ADN sérique du virus de l'hépatite $B(A D N-V H B)$ et de l'antigène e du VHB ( $\mathrm{HBe} A g)$ avec apparition d'anticorps anti$\mathrm{HBe}$, et une normalisation des aminotransferases. Nous rapportons ici notre expérience chez 22 patients avec hépatite chronique $B$ traités par l'interféron à une dose de 5 millions d'unités $/ \mathrm{m}^{2}$ par voie souscutanée trois fois par semaines pendant 16 semaines. Avant le traitement, tous les patients étaient positifs pour l'antigène de surface du VHB (HBsAg) et l'HBeAg depuis au moins 6 mois, avaient des aminotransférases anormales, n'avaient pas d'infection concommittante par les virus de l'hépatite $\mathrm{D}$ et le virus de l'imunodéficience humaine (VIH) et avaient une maladie hépatique bien compensée. Onze des 22 patients $(50 \%)$ ont présenté une réponse favorable au traitement avec disparition de l'HBeAg, apparition d'anticorps anti-HBe, et normalisation des aminotransferases 6 mois après l'arrêt de l'interféron. Après l'arrêt du traitement, les patients ont été suivis pendant une période moyenne de $3.4 \pm 1.2$ ans. Chez 10 des 11 répondeurs, l'HBeAg et l'ADN-VHB sont demeurés négatifs alors qu'un des onze répondeurs a présenté une rechute et a répondu à un second traitement à l'interféron. Durant le suivi à long terme des 11 non-répondeurs, 7 ont éventuellement fait une séroconversion de $\mathrm{HBeAg}$ à anti-HBe avec disparition de l'ADN-VHB, soit de façon spontanée $(n=5)$ ou suite à un retraitement $(n=2)$, alors que 4 non-répondeurs sont demeurés positifs pour l'HBeAg et l'ADN-VHB. Trois de ces quatre patients ont développé une maladie hépatique sévère décompensée. Ces résultats indiquent que l'interféron est un traitement efficace de l'hépatite chronique $\mathrm{B}$ chez $50 \%$ des patients présentant les critères de sélection utilisés dans cette étude. Ces critères de sélection identifient probablement aussi les patients ayant une probabilité élevée de faire une séroconversion spontanée, et il est possible que l'intérêt de l'interféron soit d'accélérer la survenue de cette séroconversion.

Division of Hepatology, Hôpital Saint-Luc, Université de Montréal, Montréal, Québec

Correspondence and reprints: Dr Jean-Pierre Villeneuve, Liver Unit, André-Viallet Clinical Research Centre, Hôpital Saint-Luc,

264, René- Lévesque est, Montréal, Québec H2X 1P1. Telephone 514-281-2446, fax 514-281-2492

Received for publication March 29, 1995. Accepted June 26, 1995 
$\mathrm{T}$ he natural history of chronic hepatitis B can be divided into two phases: an initial replicative phase and a later nonreplicative phase (1). During the initial phase, there is ongoing viral replication, hepatic inflammation and liver cell necrosis. Hepatitis $\mathrm{B}$ e antigen ( $\mathrm{HBeAg}$ ) and hepatitis $\mathrm{B}$ virus (HBV)-DNA are present in the blood, and serum aminotransferases are usually elevated. This initial phase may last only a few months or years in some subjects, but may persist for decades in others. Some authors have further subdivided the replicative phase into an immune tolerance phase followed by an immune clearance phase to account for the observation that serum transaminases can be initially normal, particularly in carriers of Asian origin (2). At some stage in the natural history of the disease, viral replication stops or decreases, with the disappearance of HBeAg, appearance of anti-HBe antibodies and normalization of liver enzymes. Seroconversion from HBeAg to anti-HBe is usually followed by an improvement in symptoms and a reduction in hepatic inflammation and liver damage. HBV-DNA is no longer measurable by conventional hybridization assays, but can be detected in serum by sensitive molecular amplification techniques. It may therefore be more appropriate to describe this phase as low replicative or latent hepatitis B infection. Carriers usually remain hepatitis B surface antigen (HBsAg)-positive. The mechanisms responsible for spontaneous $\mathrm{HBeAg}$ to anti-HBe seroconversion are still poorly understood (3). According to the length and severity of the initial replicative phase, HBsAg carriers may have histological lesions ranging from near-normal liver to severe cirrhosis with hepatic failure. The aim of chronic hepatitis B treatment is to induce an early transition from the replicative to the nonreplicative phase and stop the progression of the disease.

Several clinical trials have shown that interferon treatment induces $\mathrm{HBeAg}$ to anti-HBe seroconversion in 30 to $40 \%$ of treated patients, and a loss of HBsAg in 5 to $10 \%$ (4-6). In a recent meta-analysis (7), the difference in the percentage of treated and control patients losing HBeAg was $21 \%$. Other antiviral agents (adenine arabinoside, acyclovir, ganciclovir, foscarnet) are less effective, and some new drugs (famciclovir, lamivudine) are being evaluated. We report our experience in the treatment of chronic hepatitis B with interferon in a usual clinical setting (ie, outside of controlled clinical trials).

\section{PATIENTS AND METHODS}

Patients: From 1988-92, 22 patients with chronic hepatitis B were treated with interferon in a prospective uncontrolled fashion. The selection criteria used were as follows: positive HBsAg and HBeAg in serum for at least six months before treatment; abnormal aminotransferases (aspartate aminotransferase [AST] and/or alanine aminotransferase [ALT] greater than $40 \mathrm{IU} / \mathrm{L}$ ); compensated liver disease (absence of ascites, hepatic encephalopathy and variceal bleeding, and serum bilirubin less than $50 \mu \mathrm{m} / \mathrm{L}$ and serum albumin greater than $28 \mathrm{~g} / \mathrm{L}$ ); absence of antibodies against human immunodeficiency virus (HIV) (anti-HIV) and against

\begin{tabular}{|c|c|}
\hline Feature & Value* $^{*}$ \\
\hline Age (years) & $40 \pm 9$ \\
\hline \multicolumn{2}{|l|}{ Sex } \\
\hline $\begin{array}{l}\text { Male } \\
\text { Female }\end{array}$ & $\begin{array}{r}18(82 \%) \\
4(18 \%)\end{array}$ \\
\hline \multicolumn{2}{|l|}{ Ethnic origin } \\
\hline $\begin{array}{l}\text { French Canadian } \\
\text { Other }\end{array}$ & $\begin{array}{c}20(91 \%) \\
2(9 \%)\end{array}$ \\
\hline \multicolumn{2}{|l|}{ Risk factors for hepatitis B } \\
\hline Homosexuality & $8(36 \%)$ \\
\hline Hospital work & $7(32 \%)$ \\
\hline Immigrant from areas with high endemicity & $2(9 \%)$ \\
\hline Transfusion & $1(4.5 \%)$ \\
\hline Intravenous drug abuse & $1(4.5 \%)$ \\
\hline Unknown & $3(14 \%)$ \\
\hline Number of years known as HBsAg carrier & $3.3 \pm 2.5$ \\
\hline Aspartate aminotransferase (IU/L) & $180 \pm 167$ \\
\hline Alanine aminotransferase (IU/L) & $254 \pm 243$ \\
\hline Bilirubin $(\mu \mathrm{mol} / \mathrm{L})$ & $15 \pm 9$ \\
\hline Albumin (g/L) & $39 \pm 5$ \\
\hline Prothrombin time (seconds above control) & $1.0 \pm 0.8$ \\
\hline Hepatitis B virus-DNA (ng/L) & $199 \pm 307$ \\
\hline \multicolumn{2}{|l|}{ Liver biopsy } \\
\hline Chronic hepatitis & $5(23 \%)$ \\
\hline Chronic hepatitis with cirrhosis & $17(77 \%)$ \\
\hline
\end{tabular}

hepatitis D virus (HDV) (anti-HDV); and liver biopsy confirming a diagnosis of chronic hepatitis $\mathrm{B}$ and excluding other causes of liver disease.

Treatment: Patients were treated with $5 \mathrm{MU} / \mathrm{m}^{2}$ recombinant human interferon alpha-2b administered subcutaneously three times a week for 12 to 20 weeks. The first three doses were administered at the out-patient clinic for the teaching of drug auto-administration. Patients were seen at the out-patient clinic at one, two and four weeks after the beginning of treatment and every four weeks thereafter, then at one and six months after the end of treatment and every six to 12 months thereafter. At each visit, patients were questioned and examined; blood was drawn for complete blood count, liver enzymes determination and hepatitis B serology, and urine was obtained for routine analysis. During the treatment and follow-up period, patients received only interferon as an antiviral agent.

Definition of response to treatment: A favourable response to treatment was defined as the loss of $\mathrm{HBeAg}$ and the appearance of anti-HBe occurring within six months of treatment completion.

Laboratory methods: Serum AST and ALT, albumin, bilirubin and complete blood counts were measured by standard laboratory procedures. $\mathrm{HBs} \mathrm{Ag}$ and anti-HBs, $\mathrm{HBeAg}$ and anti-HBe, anti-HDV and anti-HIV were measured by immunoenzymatic assays (ELISA, Abbott Laboratories, Illinois). Antibodies to hepatitis $\mathrm{C}$ virus (HCV) (anti-HCV) were measured with a second-generation ELISA test (HCVELISA; Ortho Diagnostic Systems, New Jersey). HBV-DNA 
TABLE 2

Effects of treatment with interferon in 22 patients with chronic hepatitis $B$

\begin{tabular}{|c|c|c|c|c|c|c|}
\hline & \multicolumn{3}{|c|}{ Responders ( $n=11)$} & \multicolumn{3}{|c|}{ Nonresponders $(n=11)$} \\
\hline & \multirow{2}{*}{$\begin{array}{c}\text { Before treat- } \\
\text { ment }\end{array}$} & \multicolumn{2}{|c|}{ After treatment } & \multirow{2}{*}{$\begin{array}{c}\text { Before treat- } \\
\text { ment }\end{array}$} & \multicolumn{2}{|c|}{ After treatment } \\
\hline & & One month & Six months & & One month & Six months \\
\hline HBeAg-positive (\# of cases) & 11 & 2 & 0 & 11 & 11 & 11 \\
\hline Anti-HBe-positive (\# of cases) & 0 & 9 & 11 & 0 & 0 & 0 \\
\hline HBsAg-negative (\# of cases) & 0 & 3 & 3 & 0 & 0 & 0 \\
\hline Aspartate aminotransferase (IU/L)* & $232 \pm 192$ & $49 \pm 29$ & $33 \pm 11$ & $129 \pm 118$ & $71 \pm 31$ & $185 \pm 213$ \\
\hline Alanine aminotransferase $(\mathrm{IU} / \mathrm{L})^{*}$ & $337 \pm 299$ & $61 \pm 51$ & $35 \pm 9$ & $172 \pm 124$ & $91 \pm 31$ & $225 \pm 204$ \\
\hline Hepatitis B virus-DNA (ng/L)* & $220 \pm 400$ & $8 \pm 19$ & $0 \pm 0$ & $178 \pm 164$ & $156 \pm 142$ & $183 \pm 228$ \\
\hline
\end{tabular}

${ }^{*}$ Results expressed as mean $\pm S D$. HBeAg Hepatitis $B$ e antigen; HBsAg Hepatitis $B$ surface antigen

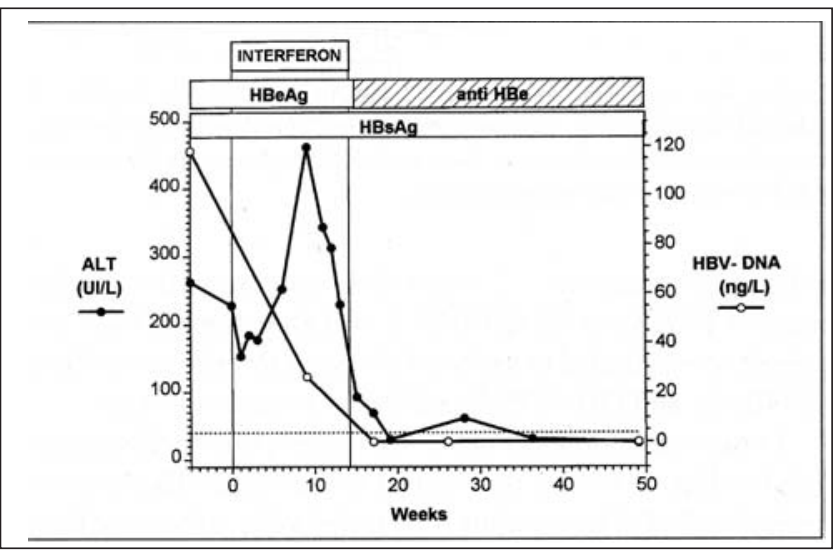

Figure 1) Representative example of a favourable response to interferon alpha $2 b$ treatment with seroconversion from hepatitis $B$ e antigen (HBeAg) to anti-HBe, loss of hepatitis B virus (HBV)-DNA and normalization of liver enzymes. Hepatitis B surface antigen ( $\mathrm{HBs} A g)$ remained positive. The dashed line is the upper normal limit of serum alanine aminotransferase (ALT)

was measured in serum by a solution hybridization assay using an ${ }^{125}$ I-labelled probe (Genostics, Abbott Laboratories) (8). Slides of liver biopsies were assessed by standard histological criteria (9), and HBsAg and hepatitis B core antigen ( $\mathrm{HBcAg})$ in paraffin sections were demonstrated by an immunoperoxidase method (10).

Statistics: Data were analyzed according to an intention-totreat strategy, and no patient was excluded from analysis even if treatment was incomplete. Results are expressed as mean $\pm \mathrm{SD}$. Differences between responders and nonresponders were assessed by Fisher exact test, $\chi^{2}$ test and Student's $t$ test.

\section{RESULTS}

Patients: The clinical and biological features of the study group are presented in Table 1 . Twenty patients were of French-Canadian origin and two came from countries with high hepatitis B endemicity (Greece and Haiti). The major risk factors for the acquisition of hepatitis B were homosexuality (36\% of cases) and hospital work with frequent exposition to blood (32\%). All patients were positive for $\mathrm{HBsAg}$ and $\mathrm{HBeAg}$ for at least six months, had abnormal liver enzymes and were negative for anti-HDV and anti-HIV. One patient was positive for anti-HCV. Liver histology showed

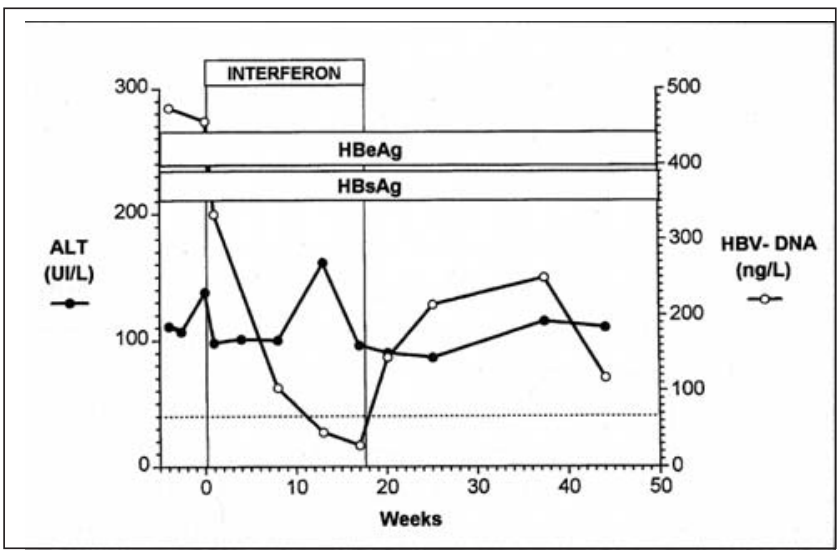

Figure 2) Representative example of interferon alpha $2 b$ treatment failure, with persistence of hepatitis B surface antigen ( $\mathrm{HBs} A g)$ and hepatitis $B$ e antigen ( $\mathrm{HBe} A g)$. Hepatitis B virus (HBV)-DNA level decreased during treatment but increased following cessation of treatment. The dashed line is the upper normal limit of serum alanine aminotransferase $(\mathrm{ALT})$

cirrhosis in a majority of cases, with positive staining for $\mathrm{HBcAg}$ in all cases.

Response to treatment: Eleven of 22 patients responded to treatment, with loss of $\mathrm{HBeAg}$ and appearance of anti-HBe at six months after discontinuing interferon. In three of 11 responders, there was also a loss of HBsAg with appearance of anti-HBs. Biological data before and after treatment in responders and nonresponders are compared in Table 2.

A representative example of treatment success is shown in Figure 1. In the majority of responders, HBV-DNA became undetectable between eight and 16 weeks after treatment initiation, followed shortly by the seroconversion from $\mathrm{HBeAg}$ to anti-HBe. HBeAg to anti-HBe seroconversion was preceded by a transient and significant rise (at least twice the basal value) of AST and ALT aminotransferases in only four of 11 responders.

A representative example of treatment failure is shown in Figure 2. HBV-DNA levels decreased during treatment in nonresponders, but rose to initial values following the end of treatment. In three nonresponders, a rise of aminotransferases to at least twice the basal value was observed after eight to 12 weeks of treatment, but was not followed by HBeAg to anti-HBe seroconversion. 


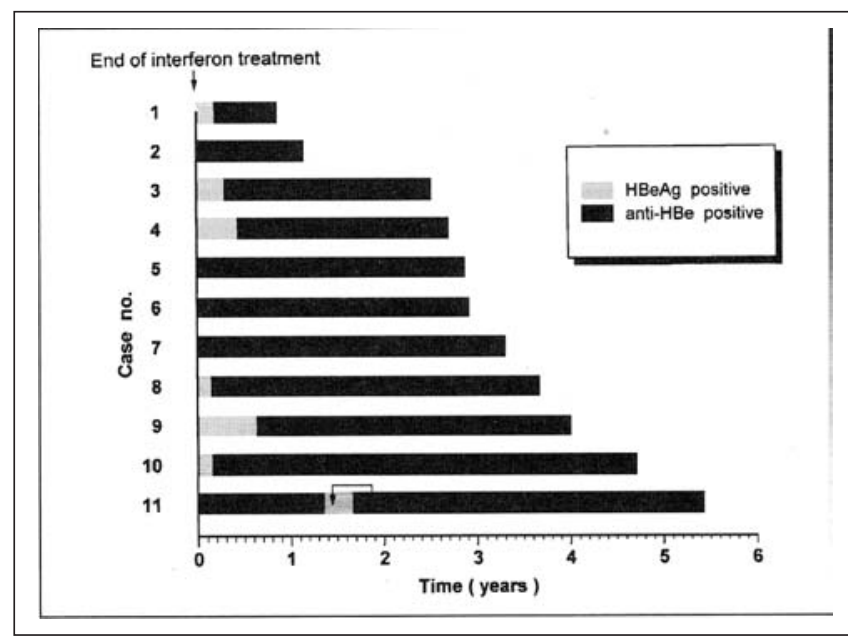

Figure 3) Long term follow-up in 11 patients with chronic hepatitis B who responded to interferon treatment. The short arrows indicate retreatment with interferon. $\mathrm{HBeAg}$ Hepatitis B e antigen

Prediction of treatment response: Comparison of baseline clinical and laboratory data reported in Table 2 did not show significant differences between responders and nonresponders. Baseline AST and ALT levels were slightly higher in responders than in nonresponders (AST: $232 \pm 192$ versus $129 \pm 118 \mathrm{IU} / \mathrm{L} ; \mathrm{ALT}: 337 \pm 299$ versus $172 \pm 124 \mathrm{IU} / \mathrm{L})$, but the difference between the two groups was not significant. Baseline HBV-DNA levels were also comparable in responders and nonresponders $(220 \pm 400$ versus $178 \pm 164 \mathrm{ng} / \mathrm{L})$. The proportion of patients with cirrhosis was similar (nine of 11 responders versus eight of 11 nonresponders) as was the known duration of disease before treatment (2.9 \pm 2.5 versus $3.6 \pm 2.8$ years).

Side effects and toxicity of treatment: The usual side effects of interferon were seen in the majority of cases: fever, myalgia and headache after the initial doses, which decreased in intensity with further dosing; and fatigue, anorexia, irritability, leukopenia (neutropenia) and thrombocytopenia lasting the entire treatment period. In three cases, the dose of interferon was decreased because of significant neutropenia (neutrophil count less than $750 \times 10^{9}$ cells/L) but treatment was maintained. In three other cases, treatment was discontinued prematurely. One patient presented severe allergic reactions at the site of interferon injection and treatment was discontinued after five weeks; he remained HBeAg-positive. A second patient developed jaundice (serum bilirubin $97 \mu \mathrm{mol} / \mathrm{L}$ ) and marked elevation of liver enzymes (ALT 1908 IU/L) eight weeks after starting interferon and treatment was stopped. In this patient, liver enzymes decreased progressively over the following months, with loss of HBeAg and appearance of anti-HBe six months after stopping interferon. A third patient decided to use natural products and discontinued interferon after 10 weeks; he did not respond to treatment.

Long term follow-up: Following the end of treatment, patients were followed for an average of $3.4 \pm 1.2$ years. All but one responder remained $\mathrm{HBeAg-negative} \mathrm{and} \mathrm{anti-HBe}$ positive with normal liver enzymes (Figure 3 ). One responder

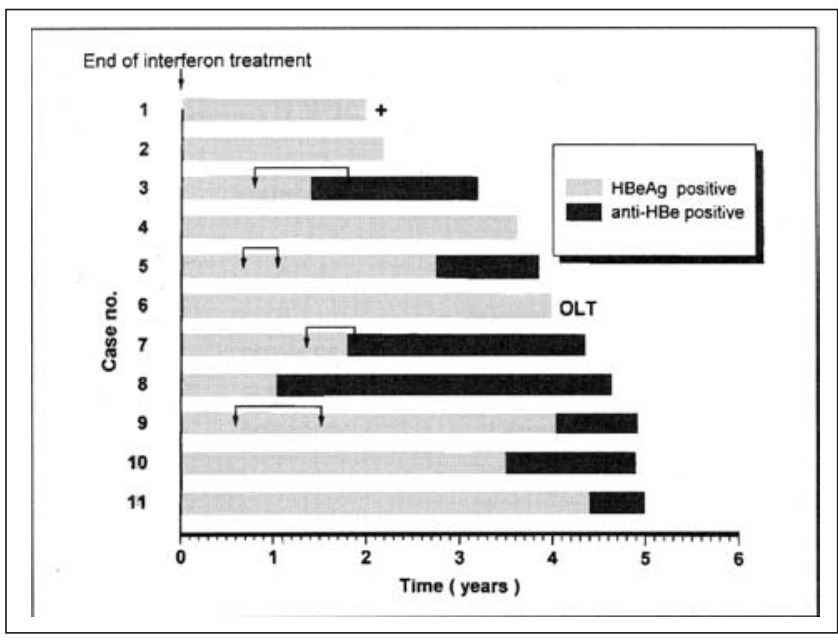

Figure 4) Long term follow-up in 11 patients with chronic hepatitis B who did not respond to interferon treatment. The short arrows indicate retreatment with interferon. + Deceased; $\mathrm{HBeAg}$ Hepatitis B e antigen; OLT Orthotopic liver transplantation

relapsed 46 weeks after the end of treatment, with reappearance of HBeAg and HBV-DNA and elevation of liver enzymes; he responded to a second course of interferon with loss of HBeAg and HBV-DNA and has not relapsed since.

Long term follow-up in the 11 nonresponders is summarized in Figure 4. Four patients have remained $\mathrm{HBeAg}$ positive: one died of liver failure, one underwent orthotopic liver transplantation, one has decompensated liver disease (Child-Pugh class C) and one remains asymptomatic. Four nonresponders were retreated with a second course of interferon: two seroconverted from $\mathrm{HBeAg}$ to anti-HBe during retreatment, and the other two did not respond but eventually underwent spontaneous seroconversion during follow-up. The remaining three nonresponders also underwent spontaneous seroconversion during follow-up.

\section{DISCUSSION}

In this study, we examined the efficacy of interferon to treat chronic hepatitis B in a usual clinical setting, ie, outside the context of randomized controlled trials. Interferon induced seroconversion from $\mathrm{HBeAg}$ to anti-HBe in $50 \%$ of patients. These results are better than those generally reported in the literature (35\% rate of seroconversion) and are probably due to the absence of factors predictive of a poor response to treatment in our study group. It has been shown that the response to interferon is lower in patients who are anti-HIV positive, who have a co-infection with HDV and who are positive for HBeAg but have normal liver enzymes (5). We chose not to treat such patients. In addition, none of our patients was of Asian origin, an ethnic group in whom the response to interferon seems less favourable (11).

In patients who responded to treatment, interferon induced a progressive decrease of HBV-DNA blood levels, which became nondetectable after eight to 16 weeks of treatment (Figure 1). In nonresponders, there was a similar decrease of HBV-DNA levels but without complete disappearance, and levels rose to initial values when treat- 
ment was stopped (Figure 2). This profile suggested that a treatment duration of more than 16 weeks could have been beneficial in some nonresponders; thus, four nonresponders were retreated with interferon for periods ranging from 20 to 32 weeks. Two nonresponders responded with a loss of $\mathrm{HBeAg}$ at the end of retreatment; the other two lost $\mathrm{HBeAg}$ 1.5 and 2.5 years after retreatment and were considered to have had spontaneous seroconversion. Controlled trials are underway to evaluate the effect of prolonged treatment or retreatment in patients who failed a conventional 16-week treatment with interferon.

Patients included in this study all had compensated liver disease, even though $77 \%$ of them had cirrhosis. The proportion of patients with cirrhosis was comparable in responders and nonresponders. Thus the presence or absence of cirrhosis did not seem to modify the treatment response. Perillo et al (6) also reported that the response to interferon was comparable in patients with and without cirrhosis. These observations differ from those made in patients with chronic hepatitis $\mathrm{C}$, where the efficacy of interferon is better in patients without cirrhosis.

Interferon treatment was associated with side effects in a majority of patients and required close observation. Asthenia, neutropenia and thrombocytopenia were the most common side effects, but they did not require interruption of treatment. Treatment was discontinued prematurely in two of 22 patients (9\%) because of side effects. In one of these patients, treatment was stopped after eight weeks because of jaundice and a marked elevation of liver enzymes. This type of reaction is thought to be related to the sudden destruction of $\mathrm{HBV}$-infected hepatocytes by an immune reaction triggered by interferon, and it underlines the risk of using interferon in patients with severe liver disease. Flares in the underlying hepatitis during interferon treatment can lead to severe and occasionally fatal hepatic failure (12). Autoimmune hyperthyroidism and hypothyroidism are known to occur in 10 to $15 \%$ of patients during therapy or even after interferon has been stopped (13), but no case of clinical thyroid dysfunction was seen in the present study.

\section{REFERENCES}

1. Sherlock S. The natural history of hepatitis B. Postgrad Med J 1987;63:7-11.

2. Lok ASF, Lai CL. Acute exacerbations in Chinese patients with chronic hepatitis B virus (HBV) infection. J Hepatol 1990;10:29-34.

3. Hoofnagle JH, Dusheiko GM, Seeff LB, Jones EA, Waggoner JG, Bales ZB. Seroconversion from hepatitis B e antigen to antibody in chronic type B hepatitis. Ann Intern Med 1981;94:744-8.

4. Hoofnagle JH, Peters M, Mullen KD, et al. Randomized, controlled trial of recombinant human alpha-interferon in patients with chronic hepatitis B. Gastroenterology 1988;95:1318-25.

5. Brook MG, Karayiannis P, Thomas HC. Which patients with chronic hepatitis B virus infection will respond to alpha-interferon therapy? A statistical analysis of predictive factors. Hepatology 1989;10:761-3.

6. Perillo RP, Schiff ER, Davis GL, et al. A randomized, controlled trial of interferon alpha-2b alone and after prednisone withdrawal for the treatment of chronic hepatitis B. N Engl J Med 1990;323:295-301.

7. Wong DKH, Cheung AM, O'Rourke K, Naylor CD, Detsky AS, Heathcote J. Effect of alpha-interferon treatment in patients with hepatitis B e antigen-positive chronic hepatitis B. A meta-analysis. Ann Intern Med 1993;119:312-23.
Following HBeAg to anti-HBe seroconversion, only one of 11 responders relapsed during long term follow-up, and he responded to a second course of interferon. Similar data have been reported in the literature, indicating that relapse is rare following seroconversion except in patients who are immunosuppressed (ie, because of HIV injection or chemotherapy) (14). More intriguing is the observation that seven of the 11 patients who did not respond to interferon eventually seroconverted from $\mathrm{HBeAg}$ to anti-HBe during follow-up, either spontaneously or following retreatment with interferon. Seroconversion from HBe to anti-HBe tends to occur spontaneously in patients with chronic hepatitis B. In a series of $\mathrm{HBeAg}$-positive patients followed prospectively without treatment for 16 years, 91\% underwent spontaneous seroconversion (15). In the present study, a high rate of seroconversion was observed over a much shorter period. This was probably because only patients with elevated liver enzymes were considered for interferon treatment; such patients have reached the immune clearance phase of the disease, characterized by the host's attempts to clear the virus with exacerbations of hepatitis and progression of the liver disease (2). These patients have a high likelihood of spontaneous or treatment-induced clearance of $\mathrm{HBeAg}$, in contrast with the low rate of HBeAg loss in those with normal liver enzymes (ie, immune tolerance phase) $(2,5,6,11)$. During the immune clearance phase, however, patients in whom seroconversion does not occur rapidly may develop severe liver disease. In the present study, three of the four patients who remained $\mathrm{HBeAg}$-positive during follow-up developed decompensated cirrhosis.

\section{CONCLUSIONS}

Alpha-interferon for the treatment of chronic hepatitis B was effective in $50 \%$ of the patients when used in selected subjects and in a standard clinical setting. Although a significant proportion of nonresponders will eventually undergo spontaneous seroconversion, new treatment strategies are needed for those who remain $\mathrm{HBeAg}$-positive because they have a high risk of developing liver failure.

8. Kuhns MC, McNamara AL, Perillo RP, Cabal CM, Campbell CR. Quantification of hepatitis B viral DNA by solution hybridization: comparison with DNA polymerase and hepatitis $\mathrm{B}$ e antigen during antiviral therapy. J Med Virol 1989;27:274-81.

9. Scheuer PJ. Classification of chronic viral hepatitis: a need for reassessment. J Hepatol 1991;13:372-4.

10. Huang SN. Immunohistochemical demonstration of hepatitis B core and surface antigens in paraffin sections. Lab Invest 1985;33:88-95.

11. Lok ASF, Wu PC, Lai CL, et al. A controlled trial of interferon with or without prednisone priming for chronic hepatitis B. Gastroenterology 1992;102:2091-7.

12. Hoofnagle JH, Di Bisceglie AM, Waggoner JG, et al. Interferon alpha for patients with clinically apparent cirrhosis due to chronic hepatitis B. Gastroenterology 1993;104:1116-21.

13. Renault RF, Hoofnagle JH. Side effects of alpha interferon. Sem Liver Dis 1989;9:273-9.

14. Levy P, Marcellin P, Martinot-Peignoux M, Degott C, Nataf J, Benhamou JP. Clinical course of spontaneous reactivation of hepatitis $B$ virus infection in patients with chronic hepatitis B. Hepatology 1990;12:570-4.

15. Villeneuve JP, Desrochers M, Infante-Rivard C, et al. A long-term follow-up study of asymptomatic hepatitis B surface antigen-positive carriers in Montreal. Gastroenterology 1994;106:1000-5. 


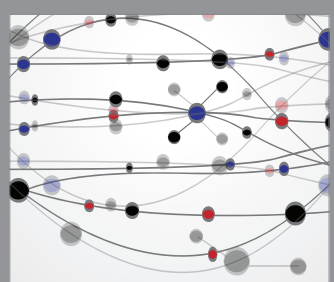

The Scientific World Journal
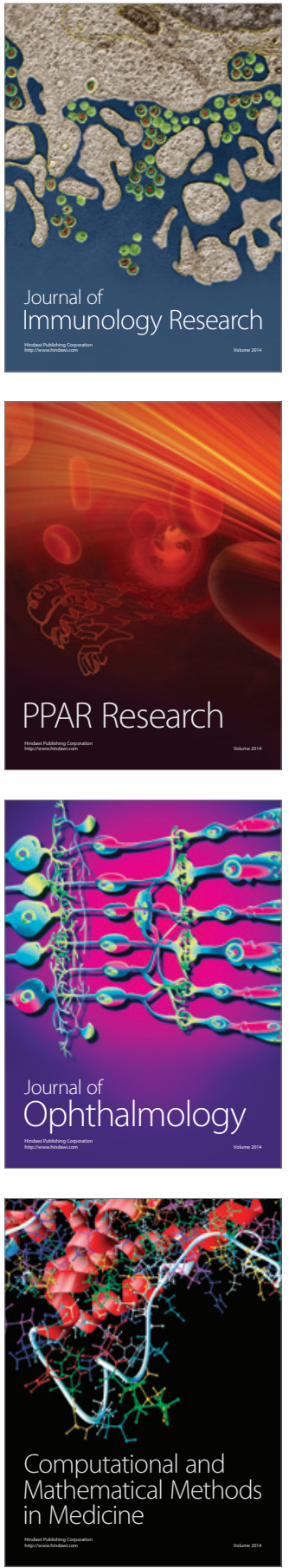

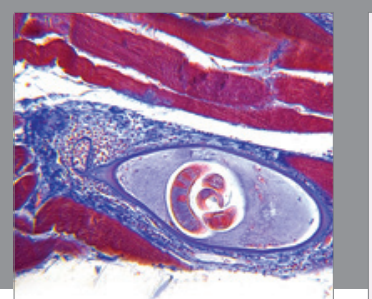

Gastroenterology Research and Practice

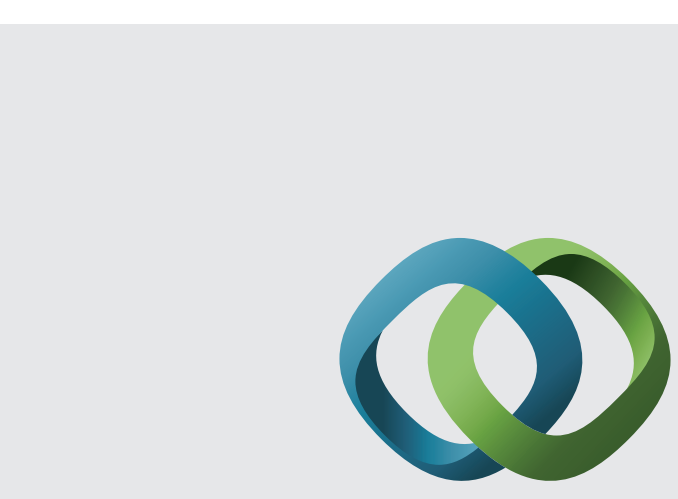

\section{Hindawi}

Submit your manuscripts at

http://www.hindawi.com
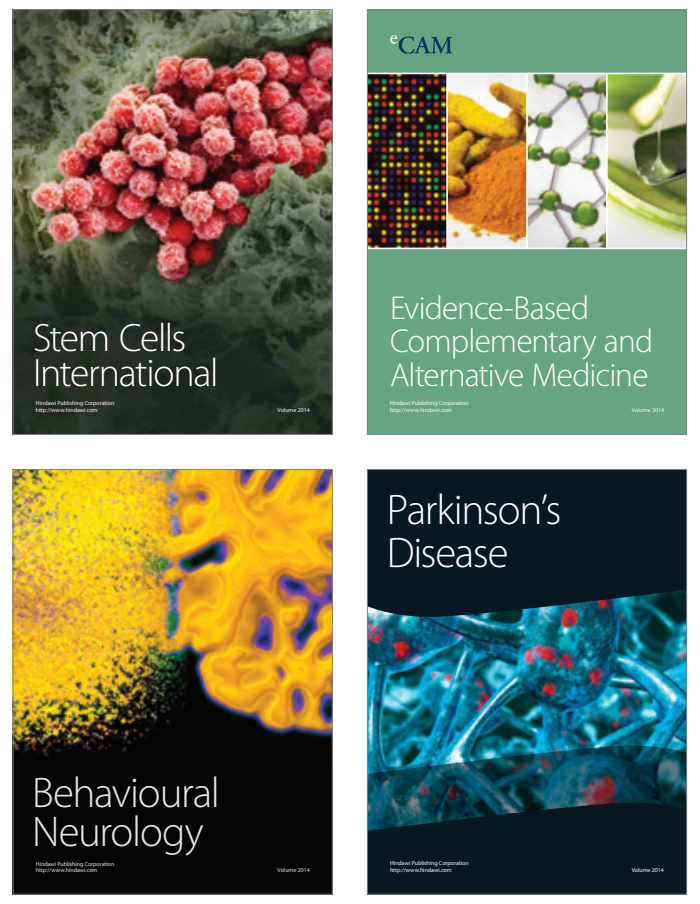
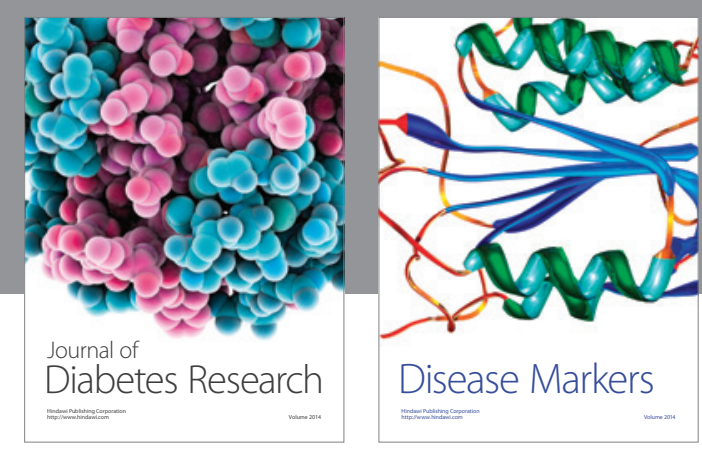

Disease Markers
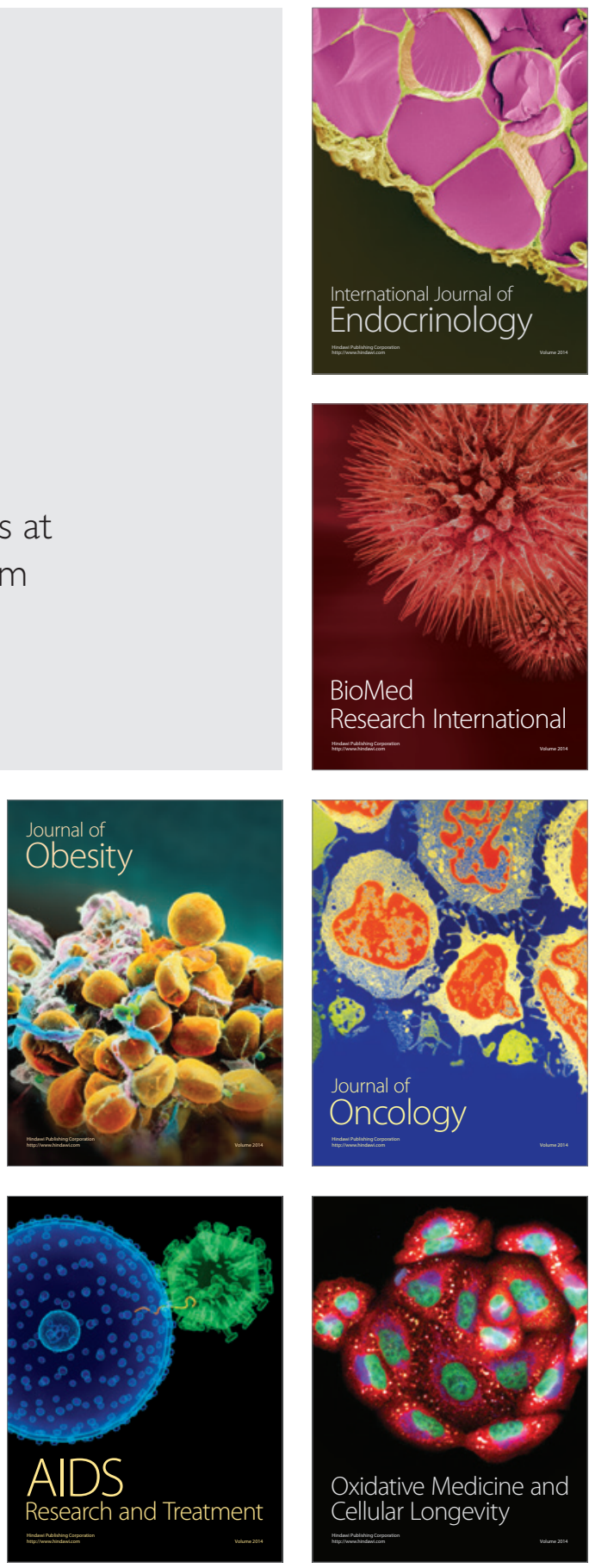